\title{
10. Post-Democracy and Populism
}

\section{COLIN CROUCH}

BRITISH DEMOCRACY reached an ugly moment on 3 November 2016, when the Daily Mail and Daily Telegraph, the country's leading press representatives of conservative opinion, devoted their front pages to displaying photographs of three judges of the Supreme Court under the banner headlines, respectively, 'Enemies of the people' and 'The judges vs the people'. The judges' offence had been to rule that Parliament had a right to have certain votes on the process of the United Kingdom leaving the European Union (EU). In subsequent days some government ministers echoed the phrases, until the Home Secretary, under pressure from judges, issued a statement stressing the importance of the rule of law. However, the government itself continued in the same spirit when it attempted later to rule that, because a majority in the referendum on EU membership had voted to leave, none of the individual measures it would implement in order to revoke EU legislation-ranging across virtually all fields of policy - needed to come to Parliament. The people had spoken; government would interpret their will. Parliament, it seemed, like the Supreme Court, was a potential enemy of that will.

This was a confrontation between two concepts of democracy: does it (as in liberal democracy) denote a set of institutions that include expressions of popular will, but which surround them with others that ensure elaboration of that will, guarantee continued debate so that democracy can function again at a future date, and even limit the powers of those who claim the right to exercise the popular will? Or is it (as in populist democracy) the direct, unmediated voice of a people expressed on a particular day? This confrontation is by no means limited to the UK or to the Brexit debate, and it is a very old theme in democratic theory. In practice, the countries that are normally regarded as stable democracies have resolved the conflict in favour of the former concept. So well established did it seem that in 1992, the US political scientist Francis Fukuyama earned lasting renown for arguing that in western liberal democracy, humankind had reached the summit of its social evolution. ${ }^{1}$ That questioning the viability of liberal democracy is now a live issue requires understanding. Equally intriguing is that fact that attacks on it from the political right, more or less silent since the fall of the Portuguese and Spanish fascist regimes in the 1970s, have returned to prominence across large parts of the world. The Marxist left has long been suspicious of liberal democracy, sometimes advocating the 'people's democracy' considered to have been achieved in the state socialist societies. Since their collapse, the left had retreated into utopian dreaming, but has more recently seen new opportunities in the waves of populism, even though these are mainly being led from the right.

(C) The Author 2019. The Political Quarterly (C) The Political Quarterly Publishing Co. Ltd. 2019 Published by John Wiley \& Sons Ltd, 9600 Garsington Road, Oxford OX4 2DQ, UK and 350 Main Street, Malden, MA 02148, USA 
A basic premise of liberal democracy is that, outside small communities, the expression of popular will is highly problematic and has to be mediated through representative institutions. There then arises the problem of the relationship between the people and the representatives whom they elect. The latter are equipped with power, which they have many temptations to abuse, ranging from simple corruption to the suppression of their opponents. The day-to-day activities of parliament as a check on the executive, the rule of law (to which governments must be subordinate), independent statistical agencies and central banks, guarantees that open debate and the organisation of opposition will continue so that there can be future, seriously contested elections, and rules about transparency and the prevention of corruption all spring logically from the fact that there will always be potential conflicts of interest between governors and governed, and that the governed must retain the right to change their minds.

The populist challenge to liberal democracy is impatient with these intermediary institutions. The people express a will, and elect a leader to execute that will - no one sensibly maintains that a people comprising several million persons can act without any mediation at all. Anything that moderates or conditions the behaviour of that leader constitutes a frustration of the people's will. Populism thus requires total faith by the people in the leader. This is its overwhelming defect. Institutions that might have protected the people from betrayal, corruption, manipulation and ultimately repression by the leader have been swept away in impatience with their apparent interference in the popular will.

This lesson is now being unlearned in many different places. As the above example shows, in the UK it is at the heart of the conflict over how democracy deals with Brexit. In the United States Donald Trump has made use of very similar themes of discontent with the functioning of institutions, making allegations of corruption against the Establishment, while his own entourage is riddled with nepotism. There was nothing about corruption in the Brexit debate, but only three years previously, the Daily Telegraph had waged a well-researched campaign against the misuse of expense accounts by Members of Parliament. While this was thoroughly justified, it seemed odd, coming from such an Establishment newspaper. Looking back now after the Brexit debates, it seems to have been part of a wider pattern of undermining parliamentary and some other institutions by the political right.

Populist movements expressing disgust with parliamentary democracy can come from the right, the left or from nowhere easily recognisable. In the French presidential elections of 2016, all major established parties were cast aside while a populist of the centre, Emmanuel Macron, beat one from the extreme right. In Hungary and Poland, nationalist rulers have increased their popularity by denouncing the institutions of liberal democracy barely a quarter of a century after their populations had celebrated ecstatically their entry into that same political form. A new far-right anti-Islamic populist group (Alternative für Deutschland) has become the third largest party in 
the German Bundestag. Two anti-Establishment parties now dominate the Italian parliament, though one (La Lega) being from the far right and the other (Movimento Cinque Stelle, M5S) of very indeterminate political colour, they do not constitute a single movement.

In 2003, I described a process that I labelled post-democracy, whereby all the institutions of liberal democracy survived and functioned, but where the vital energy of the political system no longer rested within them, but had disappeared into small private circles of economic and political elites. ${ }^{2}$ I did not say we had arrived at such a point in the settled democracies, but that we were on the road to it. ${ }^{3}$ For democracy to be flourishing, I argued, movements emerging from the population at large, unprocessed by the elite's political managers, must from time to time to be able to give the system a shock, raising new questions that the elite would sooner not discuss. I mentioned three movements that had been still capable of doing this in recent years: feminism, environmentalism and xenophobic populism. What I did not anticipate was that the lead would be taken by the last of these to a massive extent. This raises two questions: why has xenophobic populism become so dominant? Should one welcome it as a democratic irruption against the complacency of liberal post-democracy, and if not, why not?

\section{Why the popularity of xenophobic populism?}

I identified two principal causes of post-democracy-neither anybody's fault and neither easily reversed. The first was the globalisation of the economy, which took the most important issues of economic regulation beyond the reach of national politics, the level at which democracy was usually best established. The second was the decline of the social identities of class and religion that had shaped the main party identities of twentieth-century democracy. The reasons why the first of these would lead to a rejection of contacts with 'foreigners' and a desire to hunker down into the nation state are fairly clear. The role of the second is less obvious, but ultimately more important.

Most people are not highly political and usually feel remote from what goes on in parliaments and local council chambers. They will have a strong political identity only if it relates clearly to a social identity that has meaning for them. Historically this has been most likely to occur if the social identity has been relevant to struggles over inclusion in and exclusion from citizenship rights. ${ }^{4}$ For example, if one is a member of an established religion, one might want to support policies to limit the rights of those of other religions or none. If one is a member of a class excluded from political participation by property qualifications, one is likely to support parties advocating the rights of that class. Nearly all established liberal democracies have party systems based on struggles over these two key issues - class and religion-dating back to the nineteenth and early twentieth centuries. (There are exceptions, 
principally the United States and Ireland, where parties are based on outcomes of past civil wars, but these too were initially struggles over inclusion.)

Once the concept of universal adult citizenship was accepted, these identities survived as the representation of different interests within a system of overall inclusion, usually as the basis of party organisation and identity. As such, they became the central links between citizens and democracy. With time, the original struggles became a memory of the struggles of past generations rather than an experienced reality. Then the class structure itself changed, with the decline of the occupations of the industrial society on which it had been largely based. Religion too has declined in social significance (the US is again an exception). Many, probably most, people in the contemporary established democracies no longer have strong social clues to indicate a political identity for them.

Two further social identities offer themselves as candidates for struggles over inclusion and exclusion: gender and nation. The former is central to much political conflict, but it is difficult for it to become the basis of party identity, because such identities need to be rooted in communities, and men and women do not form separate communities. Nation does not have this handicap and is far more potent, being a social identity that people have long been encouraged to feel strongly, and which has clear political implications. For a long time after the defeat of fascism in the Second World War, mainstream politicians were careful not to exploit the dangerous possibilities of these. This has changed. While class and religion have declined as motivating forces for political participation, major movements of migrants and refugees, with the added frisson of occasional acts of Islamic terrorism, have raised the salience of appeals to apparently threatened national identities. If one adds to this the feelings of loss of national control facilitated by globalisation, the rise of xenophobia as a major political force presents no mysteries of understanding.

Setting the growing importance of nation against the declining salience of class and religion may also enable us to explain some otherwise puzzling features of the present situation. The advanced northern European welfare states - the Nordic countries as well as the Netherlands, Austria-all have major xenophobic populist movements, despite their wealth, low levels of social insecurity and of inequality. (Germany is a different and more complex case, because of its particular history of racist politics and its recent unification with a former communist state.) Portugal and Spain-relatively poor (especially Portugal), with less developed welfare states, high levels of inequality, recent victims of imposed austerity policies following the eurocrisis-lack such movements. It is possible to explain the paradox if one recalls that these countries did not enter liberal democracy until the 1970s, three decades later than the rest of western Europe. The hypothesis that political identities based on struggles over inclusion around class and religion 'wear out' over time should lead us to predict that these identities should be 
holding up better on the Iberian Peninsula than elsewhere in western Europe. Those struggles had been particularly harsh under the fascist regimes.

How then does one explain the particular virulence of xenophobia in central and eastern Europe, where liberal democracy is even younger, barely a quarter of a century old? Here one must remember the inversion of class struggle that had occurred under state socialism. The working class was deemed to be the leading class, but in reality, there was no political citizenship for anyone outside a tiny elite of nomenklatura. Universal inclusion was universal exclusion. It was therefore difficult for people in that part of the world to relate to the political structures familiar in the West. For a few years after 1990, it seemed that something like Christian and social democratic parties might become the basis of party systems, but these movements fragmented. There was instead a plethora of small, transient parties, with an occasionally larger movement based on a rich individual and his client groups. Meanwhile, all the formal institutions of democracy were in place. Democracy seemed very rapidly to become post-democracy.

Viktor Orbán in Hungary was the first central European ruler to realise that nationalist sentiment could provide a base for an enduring connection between politicians and a mass public. As a linguistically distinct country with various long-standing cultural minorities within its borders, Hungary was a likely location for this discovery to be made. Orbán has now been imitated by similar movements in Poland, followed by the Czech and Slovak Republics. A causus belli was provided in these cases by the EU's attempt to get the central European countries to help share the burden of refugees landing on the coasts of Greece and Italy. Poland is the only one of these countries to have a potential religious basis for party division, and the prime minister, Jarosław Kaczyński, uses it, but by itself it is problematic. In western Europe, Catholic parties are strongly pro-European. Seeking a political position largely hostile to European integration could not therefore be built on religion alone, but required a strong nationalism. Like Orbán, Kaczyński has admired the Russian regime of Vladimir Putin, a major symbolic figure for this new movement. Putin is post-democratic in using the formal institutions of democracy, while ensuring that these institutions are void of content, but populist and very different from classic post-democrats in appealing to xenophobic and traditionally conservative sentiments. At Putin's rallies banners depict himself with Trump and Marine Le Pen, the leader of the French far-right populist Front National.

Nation was potentially available as an identity that could be used by any party to refresh declining mass political attachments, but it has mainly been carried by new movements. This does not mean that established parties have not embraced it. Trump was the official candidate of the Republican party. Brexit is now the policy of both the Conservative and Labour parties. In Austria the established conservative Österreichische Volkspartei (ÖVP) turned itself into a populist anti-Islamic party. However, even these exceptions demonstrate the resistance of established parties to the xenophobic 
wave. Trump emerged as an outsider within Republican ranks, not initially favoured by the establishment. Brexit is ostensibly about a legal and economic question of membership of an international organisation and only secondarily (though powerfully) about nationalist resentment of foreigners. The ÖVP undertook its anti-Islamic turn only after it had been beaten into third place in Austrian politics by the Österreichische Freiheitspartei, itself a longstanding but outsider, post-Nazi party.

Established conservative, liberal, Christian and social democratic parties had become accustomed to relating to voters through professional media campaigns, confident that they could shape elections through top-down communication. Further, they had nearly all been complicit in the neoliberal policies that had led to the combined menace of unregulated, irresponsible global finance and declining public services that burst open in the financial crisis of 2008. It was therefore left to new invaders to articulate discontenta discontent that was then mainly targeted, not at deregulated finance and a deteriorating public realm, but at an incoherent combination of old political elites, immigrants of various kinds but especially Muslims, and international organisations.

\section{Populism as a problem}

If, as I argued in Post-Democracy, democracy expresses itself in disruptive challenges emerging from the citizenry and challenging the complacency of elites, I have to welcome the initial appearance of these various movements as refreshments for democracy. There is, however, a separate question whether the continued presence of a movement on the scene maintains that refreshment.

To consider this, we need to become more precise about what we mean by 'populist' movements. At its most general, the term refers to movements that are not contained within established political parties and which have themselves weakly structured, inchoate organisations. When they first appear, they do not behave in ways that follow the rules (formal and informal) of political conduct, but operate as the voice of their supporters, who are in general political outsiders, having neither experience of nor respect for such rules. Populist movements burst uninvited, loudly and rudely, into a room where groups of people are having polite conversations.

Beyond that point, we need to differentiate. The populist mode of politics contains three possibilities for future development, which can run into each other or can go in different directions. First, populism may simply be the form taken by a new movement when it bursts on to the scene. Newcomers who lack prior invitations cannot enter a room without disturbance, and how is change in political representation to take place without the occasional arrival of the uninvited? If an existing system of representation is wearing out, standing for social structures and issues of the past, renewal is bound to take forms disturbing to the parties of that system - the people already in 
the room, engaged in polite conversation. Naturally, these resent the intrusion and stigmatise the newcomers as populists, meaning movements that have no overall programme or roots in society, but just exploit any available discontents in order to advance their own position. If populist movements are something better than that and represent not rootlessness but interests that have been neglected, they will eventually become parties with structures and programmes; they will 'settle down' and take their place in the room, behaving like everyone else.

However, this is in itself ambiguous. It might mean that the movements stop behaving in ways that threaten the rules of behaviour that prevent abuse of power; but it might mean that they adopt practices that they had criticised during their earlier phase. For example, the German Green party, originally a disruptive outsider, eventually became part of governing coalitions. Some of its leaders later became lobbyists for motor industry and energy corporations. In Italy, M5S draws much of its energy from attacks on the corruption that is rife in Italian public life. It became a major force in local politics in 2016 when its candidates won mayoral elections in Rome and Turin. Within months, both mayors were involved in corruption scandals around public contracts.

A second possibility is that populist movements do not seek to become the 'new normal' in a renewed party system, but want to continue confronting established politics with a different way of doing public business, one less institutionalised and bearing the direct voice of the people. Strictly speaking, populist movements have no fixed substantive policy agenda, but follow what 'the people' demand. Oddly for movements that despise formal procedures, they represent a procedural form of politics; it is the way in which the voice of the people is heard that matters to them, not the content of that voice. M5S has until now been a fairly pure form of that approach. It has been clearly driven by discontent with how the Italian political elite behaves; its policies on actual issues are formed through crowd-sourcing.

The question of breaking with formal rules and, in particular, impatience with intermediary institutions that check the exercise of democratically elected power, brings us to the third question of the direction in which populism moves, and to the core issue of whether its continuity makes the same contribution to democracy as its initial irruption. On the one hand, the notion of direct people power is always a sleight of hand. There are always leaders whose job it is to interpret the people's will, and whom the advocates of populism have to view as the incorruptible, unmediated voice of the people. This was well analysed by Yves Mény and Yves Surel in their prescient 2001 study of populism, when the current resurgence was in its infancy. ${ }^{5}$ Populist movements, they argued, always required a charismatic leader in whom total trust was placed, as populism is intolerant of intermediary institutions. This requires a naïve view of the perfection of the human nature of leaders. On the other hand, established elites and wealthy interests are usually in a good position to make those institutions work for 
them. They own the property that under a system of private ownership provides protection from the power of the state; can afford to take cases through law courts; can afford to own and control the means of mass communication.

Human history is replete with cases where central power is grasped by individuals and small groups speaking in the name of the people to challenge the institutionalised rule of wealthy families and organisations, often but not necessarily going on to become dictators oppressing the people who supported them in the first place. The original Greek tyranoi were leaders of people whose interests were excluded from consideration in polities dominated by aristocratic interests. Having no formal possibilities for representing these interests, they used extra-institutional means, like mercenary soldiers, to do so. Sometimes they then used those means to support their personal positions against everyone else in the society, giving birth to our modern understanding of the word tyrant as a ruler necessarily oppressive and vicious - a change in the meaning that was first engineered by Plato. The French and Russian revolutions echoed that ambiguity in more recent centuries. But the problems faced by tyranoi in trying to represent those without means of representation were real.

The most prominent modern example of a successful populist leader was Huey Long, governor of Louisiana during the 1930s. He burst on to the political scene, taking over the state Democratic party at the head of groups outside the party's normal power structures, introduced the most radically egalitarian public policies ever seen in the US, and was confronted by the might of the oil companies, who tried to use the law to stop him taxing their activities. To consolidate his power base, he used political clientelism in appointing people to jobs throughout the public administration and interfered in the appointment of judges. He was assassinated by the son-in-law of a judge whom he was trying to dismiss from his post. Whether he would have dispensed with elections, had he been head of a national rather than a US-state level government, we shall never know. As it was, Long remained within democratic frameworks and abused power no more than many more orthodox politicians. He was certainly a tyrant in the pre-Platonic sense; whether he deserves the later twist to its meaning is difficult to determine.

Similar ambiguities surround the recent cases of the 'pink wave' of Latin American leaders elected during the early years of this century: most prominently Hugo Chavez (Venezuela), but also Evo Morales (Bolivia), Daniel Ortega (Nicaragua) and Rafael Correa (Ecuador). Each pursued policies of egalitarian redistribution, encountered strong opposition from displaced wealthy elites, elites usually supported by the US, and each rode roughshod over checks and balances on the exercise of power, including the rule of law. On the other hand, and unlike the right-wing dictators whom the US had often maintained in power in Latin America, they never abolished elections.

These examples all concern essentially left-oriented forms of populism, targeting wealthy national (sometimes international) elites and championing 
redistributive policies. Some of the currently important populist movements belong to this camp: Syriza in Greece, Podemos Unidos in Spain, France Insoumise, possibly M5S. The only one so far in power, Syriza, has done nothing to threaten democratic institutions or the rule of law. But far more prominent today is right-wing populism. Since by definition the political right supports established elites, especially national ones, it has to define its enemies in terms other than wealth and power. One of the most readily available forms of this are ethnic minorities, other countries, external institutions, foreigners in general. Rightist populism is therefore likely to be xenophobic. Mény and Surel listed hostility to immigrants alongside the existence of charismatic leaders as a defining characteristic of populism, a term which they confined to the rightist form.

The recent greater salience of 'foreigner' than class issues therefore helps explain why the political right has been in a better position to make use of discontent over the 2008 financial crisis, even though this was ostensibly a class issue, and therefore why the majority of new populist movements are on the right. There are exceptions. The only important centrist populist movement, Macron's En Marche, far from using xenophobia, is explicitly cosmopolitan. On the left, Syriza, Podemos Unidos and the Bernie Sanders movement in the US have avoided all use of immigration in their campaigns, though M5S, France Insoumise and the Labour party of Jeremy Corbyn have been more ambiguous.

There is an asymmetry in the relationship to established politics of rightist (xenophobic) and leftist (class-based) populism. As seen from the above examples from the Americas, leftist populism runs into an immediate confrontation with powerful interests. Although rightist populism criticises established elites, it then deflects the criticism towards foreigners, internal and external, letting the local elite off the hook, as it were. Elites under serious threat are therefore likely to accept rightist populists as the best of a bad job. This was astoundingly the case when Paul von Hindenburg, as president of Germany, appointed Adolf Hitler to be Chancellor in 1933, following elections in which the Nazi party's support had declined. The Weimar Republic was extremely unstable, and had Hitler the rightist populist not been appointed, the leftist Communist party might have been the next to threaten a takeover. Similarly, in 1922 the King of Italy called Benito Mussolini to form a government following his not particularly impressive March on Rome, to avert the risk of a communist challenge.

Donald Trump is not a fascist, though formally similar processes were at work when the Establishment of the Republican party decided to support him as its presidential candidate and subsequently to sustain him in office, despite his decidedly anti-Establishment stance. He turned popular rage at stagnating living standards, which might have focused on the banks and US capitalism in general, against Muslims and Mexicans.

While right-wing, xenophobic populism raises less of a threat to established interests than its leftist variety, it does threaten those institutions that 
surround democracy and protect citizens from their elected rulers. This happens because of the fundamental drive behind most examples of populism of all kinds, which is a belief in the inherent rightness of their cause and the rejection of all opponents as illegitimate. This was well analysed by Mény and Surel, and more recently by Jan-Werner Müller. ${ }^{6}$ The charismatic leader of a populist movement claims to speak for 'the people'. There is always a definite article here, leaving no scope for minorities. Those who do not share the majority view are therefore hostile to the people and have no democratic rights. All intermediate institutions that might stand in the way of, or modify the expression of the people's will are likewise anti-democratic enemies. Given that the people's will is singular and straightforward, it needs only one representative, the charismatic leader. There is no need for parliamentary or other debate. The people's will is revealed in a singular vote or plebiscite, after which all interpretation of its nuances is left to the leader and those entrusted by him or her. There may be subsequent general elections (as in state socialist regimes) or referenda on specific issues (as practised by Francisco Franco in Spain), but only after all organised opposition has been declared illegal, liquidated or (as in contemporary Russia) considerably handicapped by bans and arrests.

The regimes of Hitler, Mussolini and Franco were pure examples of rightist xenophobic populism. Those of the Soviet Union and its allies were cases of leftist populism, though eventually Stalin added hostility to Jews and various other types of foreigner to the initially class-oriented line. Today's instances are moderate in comparison, and it is important not to over-stress similarities between them and today. Institutions are better grounded and better able to be defended. It is therefore important to make an estimate of the strength of the threat that neither under-estimates nor exaggerates.

For example, in Hungary Orbán has used a nationalistic, anti-European, anti-Muslim and anti-Jewish rhetoric to justify changing the constitution to subordinate the law courts to political control, dominating state broadcasting media and purging many public offices of persons supporting opposition parties. However, this was done through parliamentary means. Orbán's Fidesz party had achieved a two-thirds majority, which under the country's constitution (similarly to that of many other countries) permitted constitutional change. In Poland, a similar rhetoric has been used to justify subordinating law courts to political control. This is, however, being done without parliamentary authority to make constitutional change, which is why the European Union is sanctioning Poland but not Hungary for its actions. In western Europe, xenophobic parties that have in the past held government office (Austria, the Netherlands), or hold it today (Austria again, Finland, Norway) have been as junior members of coalitions or support a minority centre-right government without holding office (Denmark). They therefore lack any power to pursue institutional destruction.

In the US and UK, we certainly observe populist attacks on institutions, but with limited effect. Trump has vilified various bodies, ranging from law 
courts to the security services. He has also made political appointments to the Supreme Court, but that has long been a vulnerable point in the US Constitution, a right exercised by all presidents. The Court derives its independence, despite the political nature of its appointments, through the fact that judges serve for life and cannot be removed, weakening the impact that any one president can have. However, towards the end of President Obama's term of office a Republican-dominated Congress refused to permit him to fill a vacant place on the court, in the eventually successful hope that there would soon be a Republican president. This would not have happened in earlier decades, but no one sees any risk that Trump will try to prevent future elections or have any power to hobble the Democratic opposition.

Brexit bears many of the hallmarks of xenophobic populism. Its campaign was targeted against internal (immigrant) and external (EU) foreigners. It was a plebiscite with decidedly anti-parliamentary overtones. The defeated minority, although large (48 per cent) is expected to surrender the usual democratic right to continue debating, and with the conversion of the Labour party to support leaving the UK, the minority has no major political voice. The rhetorical attack on claims that Parliament should submit the process to scrutiny, and the stigmatisation of the Supreme Court as 'enemies of the people' for saying that Parliament should have this role, is pure populism. Equally, so is the doctrine that the people had their right to speak on the day of the referendum; any right to vote on the issue again would be hostile to the people's will, as that will is defined as an almost sacred event happening on one day alone.

However, the British case is odd in that the populism is limited to this one issue - though it is an issue with important implications for virtually every field of policy. There is to date no hint that the intolerance of debate and opposition will be used to delegitimise political disagreement in general and no threat to future elections. Several leading advocates of Brexit have said that, outside the EU, the UK can become the 'Singapore of the Atlantic', but by this they refer to that island's weak welfare state, high level of inequality and low level of labour rights rather than to the highly flawed nature of its democracy. A further oddity is that, since the demise of the populist party, UKIP, the leadership of British right-wing populism is in the hands of core Conservative politicians and the editors of the Daily Mail and Daily Telegraph, both bastions of the Conservative Establishment. Somewhat like the Trump phenomenon, though through different means, Brexit represents a kind of palace coup populism from within the Establishment.

Recent developments in social media demonstrate the potentiality of such or even false populism. An early development in the US was the Tea Party movement founded around 2009. It is a mass populist movement supporting most policies associated with US conservative Republicans. It styles itself a grassroots movement, and gives the impression of resources pouring into it from masses of little individuals, who shape its agenda, while in reality it is heavily funded by a small number of billionaires who control its policies. 
This has led its critics to style it an 'Astroturf' movement. However, by 2016 the Tea Party seemed to be an exponent of outmoded technologies. Today, if one has the resources (which means if one is part of a very exclusive elite of the very rich) one can develop complex technologies that send out social media messages that have the appearance of coming spontaneously from masses of individuals, whereas in fact they come from one manipulative source. People are more likely to believe that an event has taken place, or that a view is sound, if it seems to come to their personal social media site from many different points than if it comes from just one. At the time of writing details are emerging of the role of a US billionaire, Robert Mercer, who through various channels funds Cambridge Analytica, a technology firm that specialises in this kind of centralised message crowding. Mercer is very close to Trump, and Cambridge Analytica was active in both the Trump and Brexit campaigns.

Ironically, this kind of manipulative artificiality was very much part of my vision of politics under post-democracy, but it is being practised by those claiming to be the populist challengers to Establishments. Rightist populism appears not as an antidote to post-democracy, but an extreme extension of it.

\section{Conclusion}

The initial irruption of populism within a society may well invigorate its democracy, bringing neglected issues to the table and putting established parties and elites on their mettle. However, unless it rapidly changes its character to accept restraining institutions, its continued presence can threaten democracy. Democracy requires the protection of the people from potential manipulation by their leaders. It endangers itself if it is deemed to justify political control over the law and other intermediary bodies. Also, there must always be another election, and opposition and government parties alike must have the right to go on debating and using political resources in preparation for that moment, and those that come after. Today's minority may become tomorrow's majority, which also means that majorities must beware how they treat minorities, as that may be their position in a few years' time. This expectation of a changing balance of power is the best safeguard we have that those currently with power will not abuse it. The tendency of populist movements to regard themselves as the perfect and final manifestation of democracy renders them as its enemies.

But the deficiencies in democratic institutions revealed by the rise of populism remain. It is essential that rallying calls to oppose populism do not lapse into defences of corruption, of the plutocratic capture of government, of party systems that do not represent society's most important divisions. Rude invaders must be welcome, provided they accept that they themselves must become subject to constraints that safeguard democracy's future. That itself will partly depend on whether new, or radically reshaped old, parties 
can locate themselves within rooted interests within the social structure, with which they are engaged in genuine two-way communication, not a postdemocratic, manipulative, top-down use of social media that pretends to speak for a 'people' defined so vaguely that it can be held to want whatever the leaders decide it wants.

But are post-industrial, post-religious, post-modern societies capable of producing such rooted interests, or are we just a mass of loosely attached individuals blown around by confusing blasts? The political right has produced an answer to that question: rootedness in nation, though many moderate conservatives and liberals will be in despair at that outcome. Do the left and centre have anything of similar strength to offer, roots in deeply felt social identities? Cosmopolitan liberalism by itself risks failing to have the courage of its lack of convictions. Debate on the left and centre must now turn to this search.

I have space here to offer just one possibility. I have written elsewhere that, just as the original labour movement was essentially a male phenomenon that interpreted the problems of all working people through the eyes of 'breadwinner' men, in post-industrial society, many of the problems of such people may be best articulated by women. ${ }^{7}$ They experience more keenly issues of work-life balance, of precariousness in the labour market, of deficiencies of care services, of the manipulation of consumers, though these are problems that men share too. They are found in large numbers working in the public and care services that embody the main challenges to both neoliberal and intolerant world views. This is unlikely to mean the formation of women's parties, and in any case the hope is that women will become the spokespeople of many men too. It does require a strong civil society surrounding formal politics with other forms of representation, including organisations that express women's continuing experience of various kinds of exclusion and the development of political agendas to counter them.

There is perhaps a further element. Much about rightist populism is very macho: from the male swaggering of leaders like Putin and Trump to the violent fringe that attaches to most xenophobic movements. Is it fanciful to see in the very recent widespread resurgence of feminism a reaction against that ugly face of masculine politics? We were all taken by surprise that, when a popular reaction against 2008 occurred, it took the form of xenophobia rather than a class critique. Perhaps the events of International Women's Day on 8 March 2018 were in turn an unexpected reaction against rightist populism.

\section{Notes}

1 F. Fukuyama, The End of History and the Last Man, New York, Free Press, 1992.

2 C. Crouch, Postdemocrazia, Bari/Rome, Laterza, 2003. Published in English in 2004 as Post-Democracy, Cambridge, Polity. 
3 I was writing some years before the financial crisis of 2008 saw saving the banks from their earlier irresponsibility accorded the highest priority in public policy; before the eurocrisis saw elected governments displaced in order to pursue strategies of bank rescue. I tried to incorporate some of their implications in 'The march towards post-democracy, ten years on', The Political Quarterly, vol. 87, no. 1, 2016, pp. 71-75.

4 For a more detailed exposition, see C. Crouch, 'Globalization, nationalism and the changing axes of political identity', in W. Outhwaite, ed., Brexit: Sociological Perspectives, London, Anthem, 2017, pp. 101-110; and C. Crouch, 'Neoliberalism, nationalism and the decline of political traditions', The Political Quarterly, vol. 88, no. 2, 2017, pp. 221-229.

5 Y. Mény and Y. Surel, Populismo e democrazia, Bologna, Il Mulino, 2001.

6 J.-W. Müller, Was ist Populismus, Berlin, Suhrkamp, 2016; published in English as What is Populism?, Philadelphia, Pennsylvania University Press, 2018.

7 Op cit, fn 4, 'Neoliberalism, Nationalism and the Decline of Political Traditions'. 